\section{Estratégias ambientais de empresas DO SETOR DE PAPEL E CELULOSE NO BRASIL}

Rodrigo Furgieri Mancini* Kelly Cristina Padilha André* Oscar Tupy**

\section{Introdução}

A Indústria de papel e celulose no Brasil desempenha um importante papel no processo de crescimento e desenvolvimento econômico. Contudo, a competição mundial, crescentemente acirrada pela busca de ampliação dos mercados, reforça a concorrência por preço e qualidade na produção dessa indústria, além de exigir um permanente monitoramento dos consumidores que vêm se apresentando cada vez mais exigentes em relação aos produtos, processos produtivos e contratos internacionais que, geralmente, requerem certificados de garantia de qualidade segundo as normas da ISO - International Standard Organization.

Conforme dados da Associação Brasileira de Celulose e Papel BRACELPA, a indústria brasileira do setor de Papel e Celulose é composta por 220 empresas estando presente com unidades industriais e plantações em 450 municípios e 16 estados brasileiros gerando 100 mil empregos diretos nas indústrias e florestas, produzindo 9 milhões de toneladas de celulose por ano $\left(7^{\circ}\right.$ do mundo $)$ 7,9 milhões de toneladas de papel ( $11^{\circ}$ do mundo). No contexto mundial a produção e consumo de papel vem crescendo significativamente. A taxa anual média para o crescimento da demanda mundial é de 3,3\%, sendo as categorias de papel do tipo imprimir e escrever as que apresentam as maiores taxas. Os maiores produtores e também consumidores são os países desenvolvidos: EUA, Japão e Canadá respondem por cerca de $47 \%$ da produção mundial e EUA, Japão e Alemanha consomem $50 \%$ de todo o papel produzido. O Brasil ocupa o $11^{\circ}$ lugar entre os países produtores e $12^{\circ}$ entre os consumidores de papel.

* Mestrando em Desenvolvimento Regional e Meio Ambiente do Centro Universitário de Araraquara - UNIARA

** Pesquisador da Embrapa Pecuária Sudeste e Professor do Mestrando em Desenvolvimento Regional e Meio Ambiente do Centro Universitário de Araraquara - UNIARA.
Os principais países exportadores de papel são Canadá, Finlândia, Suécia, e EUA atuando o primeiro fortemente em papel de imprensa, a Finlândia no tipo imprimir e escrever e os EUA em papéis para embalagem. As exportações brasileiras de papel alcançaram 1,46 milhões de toneladas em 2002.

As condições necessárias à competitividade de qualquer empresa do setor de papel e celulose são: equipamentos atualizados, economias de escala, acesso a capitais de longo prazo, produtos e processos compatíveis com os padrões estabelecidos de qualidade e de proteção ambiental e capacitação gerencial e produtiva para a condução das engenharias financeiras e comerciais. (BNDES)

Os Relatórios de Informações Anuais das empresas mostram que o setor de papel e celulose vem sofrendo o aumento da pressão quanto à qualidade ambiental, exercida em três vetores: exigência de produtos que não agridam o meio ambiente, pelo uso de tecnologias limpas e no deslocamento de matériaprima de origem florestal por papel reciclado.

O processo produtivo da industria de papel e celulose apresenta grande potencial de danos ao meio ambiente. As fibras usadas na fabricação de pasta celulósica para a produção de papel são obtidas, quase que exclusivamente à partir de matérias primas vegetais (madeira) e durante o processo de produção são utilizados produtos químicos e materiais biodegradáveis além da geração de resíduos sólidos, líquidos e gasosos, que são os principais causadores de transtornos ambientais, ou seja, desde o cultivo da matéria-prima (madeira) e sua extração, no processo produtivo e também no final do ciclo de vida de seus produtos existem riscos ambientais das formas mais diversificadas.

Neste contexto, conhecer apenas o setor, porém, não é suficiente, visto que os níveis de tecnologia e de produção podem variar muito de uma região para a outra e mesmo de uma empresa para outra. Nesta direção, o presente estudo tem por objetivo analisar as estratégias ambientais desta indústria, ou seja, verificar quais as ações, responsabilidades, práticas, procedimentos, processos e recursos empregados pelas empresas do setor no Brasil e no exterior para melhoria e preservação do meio ambiente.

\section{Revisando questões ambientais fundamentais}

\section{Evolução das questões ambientais}

Nas últimas três décadas ocorreu uma ampliação do nosso conhecimento empírico sobre o funcionamento da biosfera e sobre os riscos possíveis de acidentes nucleares e químicos, de aquecimento global da atmosfera e do efeito estufa, além das ameaças à segurança representadas pelos conflitos e disputas por recursos e pela guerra ecológica. Ainda nesse período, a preocupação com o estado do meio ambiente entra definitivamente na agenda dos governos de muitos países e de diversos segmentos da sociedade civil organizada havendo um considerável 
avanço na institucionalização da preocupação com a gestão ambiental

Segundo Barbieri (2004), no Brasil, a política pública ambiental pode ser dividida em três fases: a primeira delas toma como critério a eficácia da ação pública e não apenas a geração de leis, pode-se apontar a década de 30 como início de uma política ambiental efetiva, quando as políticas públicas procuram alcançar efeitos sobre os recursos por meio de gestões setoriais (água, florestas, mineração, energia, etc.) para as quais foram sendo criados órgãos específicos como o Departamento Nacional de Recursos Minerais. Com relação às indústrias, até meados da década de 70, a poluição industrial ainda era vista como sinal de progresso e por isso muito bem vinda para muitos políticos e cidadãos. A segunda fase tem início com a Conferência de Estocolmo, de 1972, embora nessa ocasião o governo militar brasileiro não reconhecesse a gravidade dos problemas ambientais, defendendo a idéia de desenvolvimento econômico porém a colocação dos problemas ambientais em dimensão global exigiu do poder público uma nova postura. Em 1973, o Executivo Federal cria a Secretaria Especial do Meio Ambiente e diversos estados criam suas agências ambientais especializadas, como a Cetesb no estado de São Paulo. A lei 6.938 de 31 de agosto de 1981, que estabeleceu a política Nacional do Meio Ambiente, dá início à terceira fase, representa uma mudança importante no tratamento das questões ambientais, na medida em que procura integrar as ações governamentais dentro de uma abordagem sistêmica. Embora aprovada em 1981, sua implementação se deu efetivamente, principalmente a partir da promulgação da Constituição de 1988

A elaboração da Constituição Federal de 1988 suscitou uma série de debates sobre o meio ambiente, cujo principal desdobramento institucional foi a criação de uma agência governamental com amplas responsabilidades na condução da política ambiental, o Instituto Brasileiro de Meio Ambiente e dos Recursos Naturais Renováveis - IBAMA.

O Capítulo 6 do Titulo VIII ("Da Ordem Social") da nova Constituição é todo dedicado ao meio ambiente, e seu artigo 225 prescreve: "Todos têm direito ao meio ambiente ecologicamente equilibrado, bem de uso comum do povo e essencial à sadia qualidade de vida, impondo-se ao Poder Público e a coletividade o dever de defendê-lo e preservá-lo para as futuras gerações".

Atualmente, apoiado em legislações específicas, quase todos os países possuem ministérios ou agências para o planejamento e implementação de políticas ambientais

No âmbito empresarial, essa preocupação é ainda mais recente, embora não tenham faltado empresas e entidades empresariais que buscassem práticas ambientalmente saudáveis, mesmo quando o assunto apenas começava a despertar interesse fora dos círculos restritos de especialistas e das comunidades afetadas diretamente pelos problemas. (Barbieri, 2004)
Neste contexto, surge a consciência de que as reservas naturais são finitas, e que as soluções ocorrem através de tecnologias mais adequadas ao meio ambiente, atendendo às necessidades básicas e utilizando o princípio da reciclagem. Para as indústrias, segundo Donaire (1999) o retorno dos investimentos, antes, entendidos simplesmente como lucro e enriquecimento de seus acionistas, ora em diante, passa, fundamentalmente, pela contribuição e criação de um mundo sustentável.

As organizações estão cada vez mais preocupadas com um desempenho mais satisfatório em relação ao meio ambiente. Neste sentido, a gestão ambiental tem se configurado como uma das mais importantes atividades relacionadas com qualquer empreendimento. Além dessa ferramenta, a problemática ambiental envolve também o gerenciamento dos assuntos pertinentes ao meio ambiente, por meio de sistemas de gestão ambiental, da busca pelo desenvolvimento sustentável, da análise dos ciclos de vida dos produtos e da questão dos passivos ambientais, ou seja, o gerenciamento ambiental passa a ser um fator estratégico que a alta administração das organizações deve analisar.

\section{A recepção de resíduos pelo meio ambiente}

Como qualquer ser vivo, o ser humano retira recursos do meio ambiente para prover sua subsistência e devolve as sobras. No ambiente natural, as sobras de um organismo são restos que ao se decomporem devolvem ao ambiente elementos químicos que serão absorvidos por outros seres vivos, de modo que nada se perde. $\mathrm{O}$ mesmo não acontece com as sobras das atividades humanas, que é denominada como poluição. (Barbieri, 2004).

A tabela 1 a seguir resume alguns critérios de classificação relativos à poluição que podem ser utilizados no âmbito deste trabalho. Nessa direção utilizaremos a atividade humana industrial; meio receptor ar, água e solo e os tipos de impactos decorrentes das atividades industriais.

Tabela 1. Poluição - alguns critérios de classificação.

\begin{tabular}{|c|c|c|}
\hline Fonte de Poluiçào & Meio Receptor & Impactes sobre o Meio Ambiente \\
\hline Atividades Humanas: & Imediato: & Alcance: \\
\hline \multirow{3}{*}{$\begin{array}{l}\text { - Agricultura } \\
\text { - Geraçâo de Energia } \\
\text { - Mineraçấo } \\
\text { - Indústrias } \\
\text { - Saúde } \\
\text { - Transporte e outros }\end{array}$} & $\begin{array}{l}-\hat{A r} \\
-\hat{A} \text { gua } \\
- \text { Solo }\end{array}$ & $\begin{array}{l}\text { - Local } \\
\text { - Regional } \\
\text { - Global }\end{array}$ \\
\hline & Final: & Tīpes de Impactos: \\
\hline & \begin{tabular}{|l|} 
- Organismos \\
- Materiais \\
- Ecossistemas
\end{tabular} & $\begin{array}{l}\text { - Eutrofizaçion } \\
\text { - Acidifieşão } \\
\text { - Destruiçăo da Camada de Ozônio } \\
\text { - Perda da Biodiversidade } \\
\text { - Aquecimento Global etc. }\end{array}$ \\
\hline
\end{tabular}

Fonte: Resumido de Barbieri, 2004. 


\section{Fontes industriais de poluição da água}

A água é poluída quando as atividades humanas a tornam inadequada para um uso específico; a natureza e extensão da poluição podem ser definidas pelo uso intencionado das águas. Uma vez que os lençóis de águas são contaminados, torna-se extremamente difícil e proibitivamente caro corrigir o problema. As atividades industriais - produção de gasolina, petroquímicos e outros produtos químicos comerciais, pesticidas e herbicidas, fertilizantes, aços e outros metais e derivados da celulose - são as principais fontes de poluentes tóxicos das águas tendo como principais poluentes: os compostos orgânicos do clorinato, minerais e derivados do petróleo, fenol, nitrogênio, fósforos, mercúrio, chumbo e cádmio (Corson, 2002).

\section{Fontes industriais de contaminação dos solos}

A contaminação dos solos dá-se principalmente por resíduos sólidos, líquidos e gasosos, águas contaminadas, efluentes sólidos e líquidos, etc., ou seja, a poluição dos solos ocorrerá sempre que houver adição de compostos ao solo, modificando suas características naturais e as suas utilizações, produzindo efeitos negativos.

\section{Fontes industriais de poluição do ar}

Segundo Corson (2002), os poluentes mais comuns emitidos por atividades humanas são: o dióxido de enxofre $\left(\mathrm{SO}_{2}\right)$, óxidos nitrogenados $\left(\mathrm{NO}_{2}\right)$, monóxido de carbono ( $\mathrm{CO})$, dióxido de carbono $\left(\mathrm{CO}_{2}\right)$, componentes voláteis orgânicos (hidrocarbonetos), partículas (pequenas partículas sólidas ou gotículas líquidas) e chumbo.

Os danos com a poluição atmosférica frequentemente resultam da combinação de vários poluentes agindo juntos. Poluentes primários resultantes da atividade humana, como $\mathrm{SO}_{2}, \mathrm{NO}_{2}$, hidrocarbonetos e $\mathrm{CO}_{2}$, por exemplo, reagem com a umidade e com outras formas de poluentes secundários que não são resultantes da atividade humana, tais como ácidos sulfúricos e nítricos, ozônio e oxidantes fotoquímicos.

Um dos poluentes secundários que merece atenção neste trabalho é o ozônio que é formado quando hidrocarbonetos orgânicos voláteis e óxidos nitrogenados reagem com o oxigênio na presença da luz solar. A nível do solo, o ozônio representa um sério problema, já nas camadas altas da atmosfera age como um filtro retendo a nociva radiação ultravioleta (UV) do sol.

Evidências cada vez maiores apontam a uma destruição gradual da camada de ozônio em anos recentes. Compostos como clorofluorcarbonetos ( $\mathrm{CFCs}$ ), óxidos nitrogenados (NOx), dióxido de carbono $\left(\mathrm{CO}_{2}\right)$, halólenos e metano têm sido responsabilizados pelo rompimento da camada de ozônio (Corson, 2002).
No caso dos poluentes primários o $\mathrm{CO}_{2}$ merece atenção especial, pois responde por cerca de metade dos atuais acréscimos ao "efeito estufa" - as emissões de $\mathrm{CO}_{2}$ estão acumulando-se na atmosfera permitindo que a luz do sol penetre na superficie da Terra, mas bloqueiam a radiação do calor e o impedem de voltar ao espaço. Esse aquecimento global é também provocado por gases como o metano $\left(\mathrm{CH}_{4}\right)$, clorofluorcarbonetos ( $\mathrm{CFCs}$ ), ozônio, óxido nitroso $\left(\mathrm{N}_{2} \mathrm{O}\right)$ e outros gases de efeito estufa (greenhouse gases). (Barbieri, 2004).

\section{Gerenciamento ambiental empresarial}

Para a solução ou minimização dos problemas ambientais, uma nova postura é exigida dos empresários e administradores, que devem passar a considerar o meio ambiente em suas decisões e adotar concepções administrativas e tecnológicas que contribuam para ampliar a capacidade de suporte do planeta.

O gerenciamento ambiental segundo Reis (1995, p.10): “É um processo que objetiva, dentre suas várias atribuições as ações mais adequadas ao atendimento das imposições legais aplicáveis às várias fases dos processos, desde a produção até o descarte final passando pela comercialização, zelando para que os parâmetros legais sejam permanentemente observados, além de manter os procedimentos preventivos e proativos que contemplam os aspectos e efeitos ambientais da atividade, produtos e serviços e os interesses e expectativas das partes interessadas"

Para que a gestão ambiental tenha resultados positivos a adoção de um modelo é essencial, pois as atividades serão desenvolvidas por diferentes pessoas, em diversos momentos e locais e sob diferentes modos de ver as mesmas questões. As empresas podem criar seus modelos ou se valer dos diversos modelos genéricos de gestão ambiental que permitem orientar as decisões. $\mathrm{O}$ Quadro 2 apresenta um resumo de alguns modelos de gestão ambiental.

Nessa direção para que uma empresa passe a trabalhar com a gestão ambiental deve inevitavelmente, passar por uma mudança em sua cultura empresarial e por uma revisão de seus paradigmas, ou seja, a gestão ambiental tem se configurado como uma das mais importantes atividades relacionadas com qualquer empreendimento.

A adoção de qualquer modelo de gestão requer o uso de instrumentos, entendidos como ferramentas para alcançar objetivos específicos em matéria ambiental, como auditoria ambiental, avaliação do ciclo de vida, estudos de impactos ambientais, sistemas de gestão ambiental, relatórios ambientais e outros.

$\mathrm{O}$ Quadro 1 mostra alguns poluentes do ar e as principais fontes geradoras: 
Quadro 1. Poluentes do ar e fontes geradoras.

\begin{tabular}{|c|c|}
\hline Polueates do Ar & Fontes \\
\hline $\mathrm{SO}_{2}$ (Diáxido Sulfúrico) & $\begin{array}{l}\text { Combustầ do carvào contendo enxofre e de derivados do } \\
\text { petróleo e a fundiclo de metais nilo ferrosos. }\end{array}$ \\
\hline NOx (Oxidos Nitrogenados) & Veiculos motorizados, usinas de força e atividades industriais. \\
\hline CO (Monóxide de Carbono) & Queima incompleta de combustiveis nos veiculas motorizados. \\
\hline $\begin{array}{l}\text { Hidrocarbonetos (Compostos } \\
\text { Orgainicos Volateis) }\end{array}$ & Queima incompleta dos combustiveis fósseis. \\
\hline $\mathrm{CO}_{2}$ (Diúxido de Carbono) & Produzido principalmente pela queima de combustiveis fósseis. \\
\hline CFCs (Clorollueecarbonetos) & $\begin{array}{l}\text { Säo quimicos sintéticos pecoluzidos para serem usados em } \\
\text { refrigeradores, aerosóis, como refrigerantes e solventes, e como } \\
\text { agemtes espumantes. }\end{array}$ \\
\hline Particulas & $\begin{array}{l}\text { Poeira, vaporizaçào, fogo em florestas e a queima de certos tipos } \\
\text { de combastíveis. }\end{array}$ \\
\hline Os (Oxw̄nio) & $\begin{array}{l}\text { Através de reaçếes atmosféricas entre óxidos nitrogenados e } \\
\text { compostes orghinicos. }\end{array}$ \\
\hline Chambo & $\begin{array}{l}\text { Grande parte das emissoies de chumbo proviem da queima de } \\
\text { gasolina contendo chumbo. }\end{array}$ \\
\hline $\mathrm{CH} 4$ (metano) & Agricultura, Indústria \& Mincração \\
\hline Halógenos & Usados em extintores. \\
\hline
\end{tabular}

Fonte: elaborado a partir de Corson (2002) e Barbieri (2004)

\section{Sistema de gestão ambiental}

O Sistema de Gestão Ambiental (SGA) pode ser utilizado para a institucionalização da função gestão ambiental nas empresas compreendendo a estrutura, responsabilidades, práticas, procedimentos, processos e recursos da organização para a implantação e manutenção da gestão ambiental

Segundo Barbieri (2004) Sistema é um conjunto de partes interrelacionadas e sistema de gestão ambiental é um conjunto de atividades administrativas e operacionais inter-relacionadas para abordar os problemas ambientais atuais ou para evitar o seu surgimento.

O SGA pode ser criado pela empresa ou adotado um modelo proposto por entidades nacionais e internacionais, como o Sistema proposto pela Câmara de Comércio Internacional (ICC), e o Sistema Comunitário de Ecogestão e Auditoria (Emas), entre outros.

Qualquer SGA requer um conjunto de elementos comuns, que independem da estrutura organizacional, do tamanho e do setor de atuação, assim como política ambiental; planejamento, implementação, verificação e ações corretivas, revisão pela direção, essenciais para que a empresa alcance desempenho superior ao exigido pelas leis ambientais.
Quadro 2. Modelos de gestão ambiental.

\begin{tabular}{|c|c|c|c|c|}
\hline Modeb & $\begin{array}{l}\text { Caracteristicas } \\
\text { Básicas }\end{array}$ & Pentos Fortes & Pontes Fracos & $\begin{array}{l}\text { Algumas } \\
\text { Entidades } \\
\text { Pramoteras }\end{array}$ \\
\hline $\begin{array}{l}\text { Gestís da } \\
\text { Qualidade } \\
\text { Ambiemal } \\
\text { Total } \\
\text { (TOEM) }\end{array}$ & $\begin{array}{l}\text { Etterbios dos } \\
\text { principios e das } \\
\text { priaticas da gestlos da } \\
\text { qualidade total is } \\
\text { questbes ambiensais. }\end{array}$ & 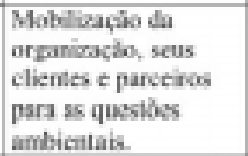 & $\begin{array}{l}\text { Depende de wim } \\
\text { esforco contimso } \\
\text { para manter a } \\
\text { motivaclos } \\
\text { inicial. }\end{array}$ & $\begin{array}{l}\text { The Glotul } \\
\text { Emironmental } \\
\text { Management } \\
\text { Init iative (GEMI). }\end{array}$ \\
\hline $\begin{array}{l}\text { Produchio } \\
\text { mais limpa }\end{array}$ &  & 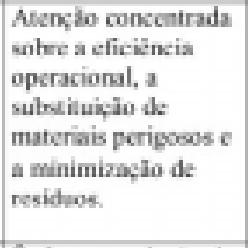 & 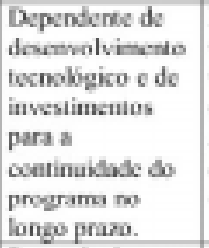 & $\begin{array}{l}\text { PNUD, Onudi } \\
\text { CNTLSenai, } \\
\text { CEBDS, Centro } \\
\text { de Estudes de } \\
\text { Administraklo e } \\
\text { do Meis Ambiente } \\
\text { (CeamaFGV). }\end{array}$ \\
\hline Eooeficos̀ncia & 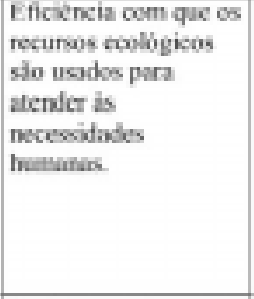 & 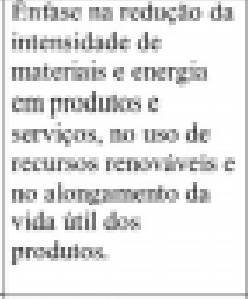 & 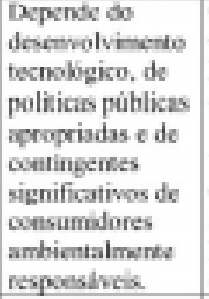 & $\begin{array}{l}\text { Otganisstion for } \\
\text { Co-Operatioes and } \\
\text { Develogment } \\
\text { (OCDE). } \\
\text { Work Business } \\
\text { Coursil for } \\
\text { Sustainable } \\
\text { Develogenent } \\
\text { (WBCSD). }\end{array}$ \\
\hline $\begin{array}{l}\text { Projecto para } \\
\text { meis } \\
\text { ambionte }\end{array}$ & $\begin{array}{l}\text { Projotar produtos e } \\
\text { proceseos } \\
\text { considerando os } \\
\text { impoctos sobre o } \\
\text { meio ambinnic. }\end{array}$ & 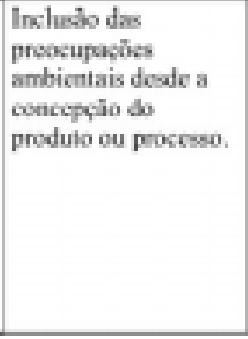 & 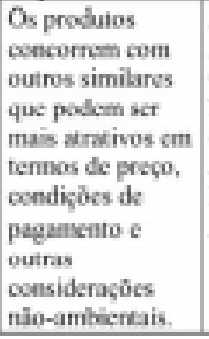 & $\begin{array}{l}\text { Agtincis } \\
\text { Ambiental do } \\
\text { Governo Foderal } \\
\text { Nortic-americano } \\
\text { (Uscpai. } \\
\text { American } \\
\text { Electronic } \\
\text { Association. }\end{array}$ \\
\hline
\end{tabular}

Fonte: Barbieri, J. C. 2004

\section{Certificação de sistemas de gestão ambiental}

A certificação é um procedimento pelo qual um terceiro fornece prova escrita de que um produto, processo ou serviço atende a determinadas normas especificadas. No caso do SGA é certificado que a organização possui uma política ambiental e que está implementada em conformidade com os requisitos da norma referencial, a ISO 14001, ou seja a organização tem um SGA totalmente implementado, que está de acordo com a norma e é operado com rigor e de forma correta.

\section{Certificação ISO 14000}

A International Organization for Standardization - ISO - é uma federação mundial composta por entidades de normalização de mais de 110 
países, com sede em Genebra, fundada em 1947 com o objetivo de promover o desenvolvimento de normas na indústria comércio e serviços, para facilitar o comércio internacional aumentando a confiabilidade e a eficácia dos produtos

O Brasil é representado pela Associação Brasileira de Normas Técnicas, a qual tem direito de voto no fórum internacional de normalização. A partir das publicações internacionais inicia-se no Brasil o processo de tradução e votação pela ABNT para transformá-las em normas brasileiras (NBR ISO).

As normas da série ISO 14000 podem ser classificadas, segundo o foco de aplicação, em duas categorias: as que se voltam para a gestão ambiental da organização - Sistema de Gestão Ambiental, Auditoria Ambiental e Avaliação do Desempenho Ambiental - e as que visam à caracterização de seu produto Rotulagem Ambiental, Avaliação do Ciclo de Vida e Aspectos Ambientais em Normas de Produtos.

As normas relativas aos Sistemas de Gestão Ambiental produzidas pela ISO foram traduzidas pela Associação Brasileira de Normas Técnicas (ABNT) e integram o conjunto de normas dessa instituição. São elas:

- a NBR ISO 14001:1996 - Sistema de Gestão Ambiental: especificações e diretrizes para uso;

- a NBR ISO 14004:1996 - Sistemas de Gestão Ambiental: diretrizes gerais sobre princípios, sistemas e técnicas de apoio.

A norma ISO 14001 foi formulada para aplicar-se a organizações de todos os tipos e porte e para adequar-se a diferentes condições geográficas, culturais e sociais. A base utilizada para esta abordagem é o aprimoramento contínuo, conforme apresentado no ciclo do SGA. A 14001 compartilha princípios gerais de gestão com a série ISO 9000 para sistemas da Qualidade. As organizações podem decidir utilizar o sistema de gestão já existente, consistentes com a série ISO 9000, como base para seu Sistema de Gestão Ambiental (Reis, 1995)

\section{Material e métodos}

Para atingir os objetivos propostos, foi estruturado um questionário composto por 45 questões abertas, fechadas e mistas que foi enviado por email às empresas que operam no Brasil e no exterior e preenchido pelos entrevistados.

O questionário elaborado engloba seções como: informações gerais do entrevistado; caracterização da empresa; certificação ISO 9000; produção e meio ambiente; implantação de medidas de proteção ambiental; gestão da qualidade da água; gestão de resíduos sólidos e gestão de resíduos gasosos. Com o intuito de completar a análise utilizou-se informações publicadas nos Relatórios de Informações Anuais das empresas.
Para a formulação deste questionário utilizou-se como exemplo o instrumento de pesquisa empregado pelo NITEC (Núcleo de Gestão da Inovação Tecnológica) da Universidade Federal do Rio Grande do Sul, nas empresas do setor metal-mecânico no Rio Grande do Sul, ao qual foram feitas as devidas adaptações à realidade das empresas do setor de papel e celulose.

A partir de fontes não oficiais como as páginas das empresas na internet e de órgãos que possuem ligação direta com estas ou com o meio ambiente foram levantadas algumas empresas.

Das 220 empresas citadas pela BRACELPA no Brasil presentes em 16 estados brasileiros, apenas 40 são associadas à BRACELPA, correspondendo as mesmas às maiores empresas do setor. Destas, somente as que dispunham de home page, um total de 32, foram contactadas, solicitando o endereço eletrônico do responsável pelo departamento de Meio Ambiente, para posterior envio do questionário

Do total de 32 empresas, apenas 6 responderam ao questionário: Celulose Irani S.A.; Klabin S.A.; Suzano Bahia Sul Papel e Celulose S.A.; MD Papéis LTDA, Papirus S.A. e Celulose Nipo-Brasileira S.A.- CENIBRA.

No caso das empresas estabelecidas em outros países traduziu-se o questionário para o inglês e por meio dos endereços eletrônicos, também em fontes não oficiais, conseguiu-se um total de 67 empresas, aplicando a mesma técnica de envio utilizada nas empresas brasileiras. Neste caso, responderam ao questionário, também 6 empresas: Western Pulp Inc. (Canadá), Ahlstrom (Finlândia, França e Alemanha), Fraser Papers, Stora Enso, UPM - Kymmene e a Tolko Industries.

\section{Estratégias ambientais da industria de papel e celulose}

\section{Informações gerais das empresas}

As empresas pesquisadas, no que se refere à origem do seu capital, caracterizam-se por pertencerem a grupos empresariais multinacionais $(n=4)$, grupos empresariais brasileiros $(n=3)$, grupo empresarial canadense $(n=1)$, sendo que as demais não pertencem a nenhum grupo empresarial, ou seja, são empresas independentes $(\mathrm{n}=4)$

De acordo com a classificação do SEBRAE Nacional industrias são consideradas pequenas quando o número de empregados é inferior a 100 funcionários; empresas médias com número de funcionários igual ou superior a 100 e inferior a 500 e grandes empresas as que empregam um número igual ou superior a 500 funcionários. A maioria das empresas desta pesquisa são de grande porte $(n=8)$ e o restante de médio porte $(n=4)$, totalizando aproximadamente 100.000 funcionários 
O principal destino da produção é para Europa, América do Norte e Ásia. O Quadro 3 abaixo mostra a percentagem que a exportação representa no faturamento total da empresa.

Quadro 3. Participação das exportações no faturamento total das empresas

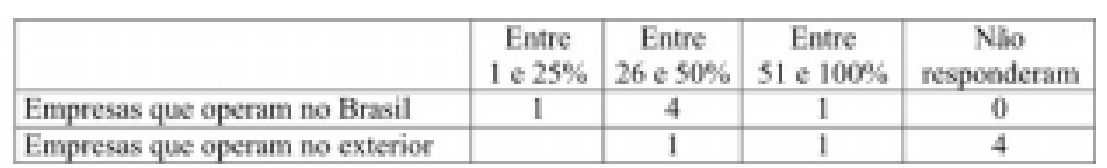

Fonte: Dados da Pesquisa.

\section{Certificações}

Com relação à certificação ISO 9000, 11 empresas são certificadas e 1 não respondeu a questão.

Já no que diz respeito a certificação ISO 14000 das empresas que operam no Brasil, 2 possuem a certificação e 4 pretendem obter, as empresas que operam no exterior 5 possuem a certificação e 1 não possui e não respondeu se pretende obter.

\section{Produção e meio ambiente}

Para a maioria das empresas, dentre as etapas críticas mais significantes do processo de produção estão: o cozimento, o branqueamento e a geração de efluentes

Com relação ao volume de investimentos em máquinas equipamentos e tecnologia na área ambiental, 3 empresas que operam no Brasil e 2 no exterior responderam, de acordo com o Quadro 4, variando os investimentos de $0,05 \%$ a $3,71 \%$ do faturamento bruto das empresas, sendo que a empresa $\mathrm{C}$ apresentou um maior volume de investimentos na área ambiental em relação ao seu faturamento bruto

Quadro 4. Volume de investimentos das empresas pesquisadas em meio ambiente.

\begin{tabular}{|c|c|c|c|}
\hline Empresas & $\begin{array}{c}\text { Faturamento Bruto no } \\
\text { ano de } 2003 \text { (USsi.ese mil) }\end{array}$ & $\begin{array}{c}\text { Investimentes na área } \\
\text { ambhiental em } 2003 \text { (USS mil) }\end{array}$ & $\begin{array}{c}\% \\
\text { Faturamente }\end{array}$ \\
\hline \multicolumn{4}{|c|}{ Empresas que eperaim no Brasil } \\
\hline A & $>342.000$ & 476 & 0,14 \\
\hline B & Naio respondeu & 684 & \\
\hline C & $>345.000$ & 13.000 & 3,71 \\
\hline \multicolumn{4}{|c|}{ Fmpresas que operam no esterier } \\
\hline c & 900.000 & $\$ 000$ & 1,00 \\
\hline D & 100.000 & 250 & 0.05 \\
\hline
\end{tabular}

Fonte: Dados da Pesquisa.
Nos últimos cinco anos somente 3 empresas do exterior disseram ter ocorrido algum tipo de acidente ambiental, mas nenhuma estimou diretamente os custos das medidas adotadas para reduzir o impacto causado, sendo as principais medidas, mudanças no processo produtivo, investigação e eliminação de todos riscos

\section{Medidas preventivas}

São as medidas utilizadas pelas empresas para reduzir o risco de possíveis acidentes ambientais. O Quadro 5 descreve as medidas preventivas das empresas que operam no Brasil e o Quadro 6 descreve as medidas preventivas das empresas que operam no exterior.

Das empresas brasileiras entrevistadas 50\% disseram participar de algum programa governamental de despoluição de bacia hidrográfica.

\section{Medidas adotadas pelas empresas para a redução dos problemas ambientais}

As principais medidas desenvolvidas pelas empresas para reduzir os problemas ambientais já existentes no processo produtivo foram: redução do consumo de energia $(n=10)$; redução das emissões de efluentes líquidos $(n=11)$; redução das emissões gasosas $(n=10)$; redução de resíduos sólidos $(n=9)$; redução de ruídos $(n=4)$ e redução de odores $(n=6)$.

As medidas menos citadas foram as ações visando a redução ruídos, apenas 33\% $(n=4)$ das empresas adotam essas medidas, sendo que 03 operam no Brasil e 01 opera no exterior.

Para 03 empresas que operam no exterior essas medidas provocaram alguma economia, as quais foram quantificadas. Para as que operam no Brasil todas disseram que as medidas provocaram alguma economia, mas apenas 04 quantificaram a redução das despesas.

\section{Gestão da qualidade da água}

Com relação a utilidade da água para a empresa todas responderam que a água utilizada é tratada e que é usada em todo o processo produtivo, sendo uma matéria-prima de grande importância.

As empresas que operam no Brasil responderam que a situação de abastecimento de água na região é a seguinte: não têm problemas pois a região tem muita oferta de água $(n=2)$, a região esta em expansão e a demanda de água tem aumentado significativamente $(n=2)$, portanto merece atenção e 02 empresas não responderam a estas questões. Para as empresas que operam no exterior todas responderam que não tem problemas com o abastecimento de água, pois a região tem muita oferta. 
Quanto ao abastecimento de água tratada todas as empresas responderam possuir um sistema próprio de abastecimento e sistemas de tratamentos de efluentes líquidos. No caso das empresas que operam no Brasil 03 responderam que pertencem a algum programa governamental de despoluição de alguma bacia hidrográfica específica.

Quadro 5I. Medidas preventivas de empresas que operam no Brasil.

\begin{tabular}{|c|c|c|c|c|}
\hline Empresa & Medidas Preventivas & Objetive & Motivo & $\begin{array}{l}\text { Custe } \\
\text { USS mil }\end{array}$ \\
\hline $\mathbf{A}$ & $\begin{array}{l}\text { - bacias de contençào; } \\
\text { - procedimernos operacionais; } \\
\text { - conscientizaçăb ambictatal; } \\
\text { - treinamento }\end{array}$ & $\begin{array}{l}\text { - utilizar as tecnologias } \\
\text { ambicmtais disponiveis } \\
\text { para tornar-se mais } \\
\text { coenectiniva. }\end{array}$ & $\begin{array}{l}\text { - exigincias de } \\
\text { autoridades } \\
\text { govemamentais; } \\
\text { - inicianiva } \\
\text { própria: }\end{array}$ & 50 \\
\hline B & $\begin{array}{l}\text { - controbe da poluiçio } \\
\text { atmosferica; } \\
\text { - tratamento biokgico de } \\
\text { efluentes; } \\
\text { - aterro industrial e celula de } \\
\text { residues classe I }\end{array}$ & $\begin{array}{l}\text { - atilizar as tecnologias } \\
\text { ambientais disponiveis } \\
\text { para tornar-se mais } \\
\text { competitiva. }\end{array}$ & $\begin{array}{l}\text { - inicianiva } \\
\text { própriz; }\end{array}$ & 30 \\
\hline c & 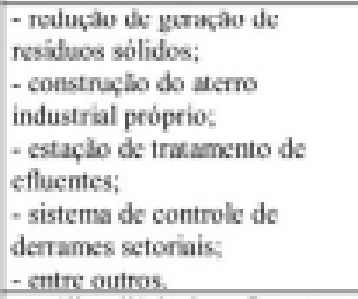 & $\begin{array}{l}\text { - manutencà̀ da } \\
\text { qualidade ambiental da } \\
\text { empresa. }\end{array}$ & $\begin{array}{l}\text { - cuigincias de } \\
\text { autoridadss } \\
\text { governamentais } \\
\text { - inicianiva } \\
\text { própri. }\end{array}$ & $\begin{array}{l}\text { - nhio } \\
\text { respondeu. }\end{array}$ \\
\hline D & $\begin{array}{l}\text { - análise diára dos efluemtes; } \\
\text { - análise mensal dos poços de } \\
\text { monitoramento; } \\
\text { - tratameme de efluentes. }\end{array}$ & $\begin{array}{l}\text { - Latilizar as tecsologias } \\
\text { ambientais disponiveis } \\
\text { para tornar-se mais } \\
\text { competiniva. }\end{array}$ & $\begin{array}{l}\text { - inicianiva } \\
\text { própriz. }\end{array}$ & $\begin{array}{l}\text { - nilo } \\
\text { respondeu. }\end{array}$ \\
\hline $\mathrm{E}$ & $\begin{array}{l}\text { - estaciolo de traciemento de } \\
\text { efluentes; } \\
\text { - sontrole de prosesso e } \\
\text { procedimentos opsraxionais; } \\
\text { - sistema de coleta seletiva de } \\
\text { mancriais }\end{array}$ & $\begin{array}{l}\text { - desenvolver o } \\
\text { marketing ecológico da } \\
\text { sempresa. }\end{array}$ & $\begin{array}{l}\text { - inicianiva } \\
\text { própriz. }\end{array}$ & $\begin{array}{l}\text { - nis } \\
\text { respondeu. }\end{array}$ \\
\hline$F$ & $\begin{array}{l}\text { - implantacão do Sistema de } \\
\text { Gestio Amboicntal. }\end{array}$ & $\begin{array}{l}\text { - Lefilizar as tecnologias } \\
\text { ambientais disponiveis } \\
\text { para tornar-se mais } \\
\text { comrectikiva. }\end{array}$ & $\begin{array}{l}\text { - inicistiva } \\
\text { própria. }\end{array}$ & $\begin{array}{l}- \text { nilo } \\
\text { respondeu. }\end{array}$ \\
\hline
\end{tabular}

Fonte: Dados da pesquisa.
Quadro 6. Medidas preventivas de empresas que operam no exterior.

\begin{tabular}{|c|c|c|c|c|}
\hline Empresa & Medidas Preventivas & Ohjetive & Motivo & Custe \\
\hline Tolks & $\begin{array}{l}\text { - tratamento de } \\
\text { efluentes; } \\
\text { - construção de siento } \\
\text { indastrial; } \\
\text { - aquisicilio } \\
\text { equipamentos de } \\
\text { controle de emissâo } \\
\text { aimosforica }\end{array}$ & Nhso respondeu & $\begin{array}{l}\text { Exigerncias de } \\
\text { autoridudes } \\
\text { govemamenkais. }\end{array}$ & $\begin{array}{l}\text { - USS } 480 \\
\text { mil }\end{array}$ \\
\hline Fraser & $\begin{array}{l}\text { - sistema de controle } \\
\text { de poluizăo do ar; } \\
\text { - tratameno de } \\
\text { efluctres; }\end{array}$ & $\begin{array}{l}\text { - utilizar as } \\
\text { tecnologias } \\
\text { ambientais } \\
\text { disponiveis para } \\
\text { tomar-se mais } \\
\text { competitiva; } \\
\text { - estar de acondo com } \\
\text { os regulamentos } \\
\text { atuais. }\end{array}$ & $\begin{array}{l}\text { Inicialina própria; } \\
\text { Exiǵbcias de } \\
\text { autoridades } \\
\text { governamemais; } \\
\text { Exigtncias de } \\
\text { parceiros e } \\
\text { acionistas. }\end{array}$ & $\begin{array}{l}\text { - nis } \\
\text { respondku. }\end{array}$ \\
\hline Stora Enso & Nino respondeu & $\begin{array}{l}\text { - utilizar o marketing } \\
\text { ecolbgico para seus } \\
\text { produtos; } \\
\text { - aproveitar as } \\
\text { opotunidades } \\
\text { financeiras; } \\
\text { - utilizar as } \\
\text { uecnologias } \\
\text { ambientais } \\
\text { disponiveis para } \\
\text { tomar-se mais } \\
\text { competitiva; }\end{array}$ & $\begin{array}{l}\text { - Inieiativa própris; } \\
\text { - Exigências de } \\
\text { autoridades } \\
\text { governamentais; } \\
\text { - Exigèncias de } \\
\text { parceirose } \\
\text { acionistas; } \\
\text { - Exigúneias de } \\
\text { clientes. }\end{array}$ & $\begin{array}{l}\text { - nis } \\
\text { respondeu. }\end{array}$ \\
\hline Westem Pulp & $\begin{array}{l}\text { - sistemus de controle } \\
\text { de poluikâo do af; } \\
\text { - tratamento de } \\
\text { efluenes; } \\
\text { - Sistema de Gestâo } \\
\text { Andbicreal. }\end{array}$ & $\begin{array}{l}\text { - utilizar o markcting } \\
\text { esoblogico para seus } \\
\text { produtos; } \\
\text { - aproveitar as } \\
\text { oportunidades } \\
\text { finarkeiras; } \\
\text { - utilizar as } \\
\text { tecnologias } \\
\text { ambientais } \\
\text { disponiveis para } \\
\text { tomar-se mais } \\
\text { competitiva; }\end{array}$ & $\begin{array}{l}\text { - Iniciativa própriz; } \\
\text { - Exigéncias de } \\
\text { autoridades } \\
\text { governumemais; } \\
\text { - Exigéncias de } \\
\text { parceirus e } \\
\text { acionistas; }\end{array}$ & $\begin{array}{l}\text { - nì } \\
\text { respondku. }\end{array}$ \\
\hline $\begin{array}{c}\text { UPM } \\
\text { KYMMENE }\end{array}$ & $\begin{array}{l}\text { - as melhores técnicas } \\
\text { dipponiveis sa } \\
\text { utilizadas }\end{array}$ & $\begin{array}{l}\text { - utilizar o marketing } \\
\text { ecolbgico para seus } \\
\text { produtos; } \\
\text { - utilizar as } \\
\text { tecnologias } \\
\text { ambientais } \\
\text { disponiveis para } \\
\text { tomar-se mais } \\
\text { competitiva; }\end{array}$ & $\begin{array}{l}\text { - Inicianiva própria; } \\
\text { - Exigéncias de } \\
\text { autoridades } \\
\text { governamentais; } \\
\text { - Exigencias de } \\
\text { parceirose } \\
\text { acionistas; } \\
\text { - Exigtencias de } \\
\text { elientes. }\end{array}$ & $\begin{array}{l}\text { - nīe } \\
\text { respondku. }\end{array}$ \\
\hline AHLSTROM & - comirole de & - utilizar o marksting & - Iniciativa própris; & - nio \\
\hline
\end{tabular}

Fonte: Dados da Pesquisa. 
Figura 1. Medidas desenvolvidas para reduzir problemas ambientais

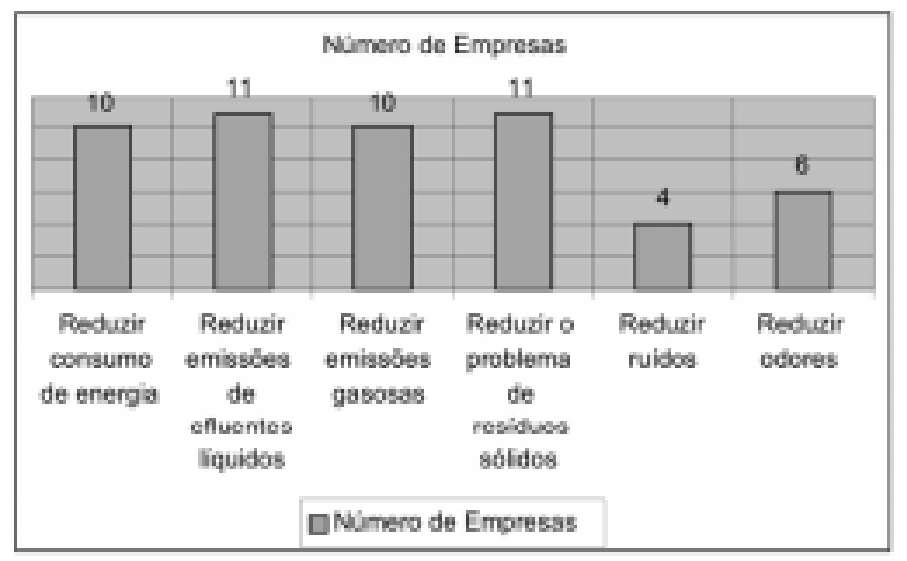

Fonte: Dados da Pesquisa.

\section{Gestão de resíduos sólidos}

Todas as empresas afirmaram que existe a geração de resíduos sólidos em seu processo produtivo. A composição principal destes resíduos consta do Quadro 8.

Com relação a redução e controle deste tipo de resíduo do total de empresas entrevistadas apenas 02 disseram não realizar investimentos nesta área, 01 que opera no Brasil e 01 que opera no exterior. Esses investimentos para as 10 empresas correspondem a trabalhos de conscientização das pessoas envolvidas no processo e aquisição e desenvolvimento de novas tecnologias.

\section{Gestão de resíduos gasosos}

Todas as empresas disseram que há geração de resíduos gasosos em seu processo produtivo e os principais gases são: $\mathrm{SO}_{2}, \mathrm{CO}_{2}, \mathrm{NOx}$, eTRS. Das empresas que operam no Brasil 4 realizaram investimentos na redução e controle deste tipo de resíduo, 01 não realiz0u investimentos e 01 não respondeu a essa questão. Com relação a existência de filtros de purificação 03 responderam possuir, 01 respondeu não possuir e 02 não responderam. O nível de purificação obtido para 02 empresas é de 90 a $100 \%$ e para 01 empresa é de 70 a $89 \%$.

Quanto as empresas que operam no exterior, 05 responderam que realizam investimentos na redução e controle deste tipo de resíduo e 01 respondeu não realizar. Com relação a existência de filtros de purificação todas as empresas disseram possuir. $\mathrm{O}$ nível de purificação obtido para 05 empresas é de 90 a $100 \%$ e para 01 empresa é de 70 a $89 \%$.
Quadro 7. A composição principal dos resíduos sólidos originados do processo produtivo.

\begin{tabular}{|c|c|c|c|}
\hline \multicolumn{4}{|c|}{ Empresas que operam no Brasil } \\
\hline Empresa & Composiçãe & $\begin{array}{c}\text { Formas de } \\
\text { Armazenagem }\end{array}$ & Destino \\
\hline B & $\begin{array}{c}\text { Madeira } \\
\text { Papel } \\
\text { Metais ferrosos } \\
\text { Metais njo ferrosos } \\
\text { Lodo Biológico }\end{array}$ & Centro de Triagem & $\begin{array}{l}\text { Reaproveitamento no } \\
\text { processo produtivo; } \\
\text { Eliminaçăo destes residuos na } \\
\text { própria empresa; } \\
\text { Eliminaçlo destes residuos } \\
\text { através de ferceiros; } \\
\text { Venda destes res iduos para } \\
\text { terceiros. }\end{array}$ \\
\hline A & $\begin{array}{l}\text { Madeira } \\
\text { Papel } \\
\mathrm{CaCO} 3\end{array}$ & $\begin{array}{l}\text { Caicas fechadas; } \\
\text { A granel no pitios } \\
\text { Aterro industrial }\end{array}$ & $\begin{array}{c}\text { Reaproveitamento no } \\
\text { processo produtivo; } \\
\text { Eliminaçāo destes residuos na } \\
\text { própria empresa; } \\
\text { Eliminaçalo destes residuos } \\
\text { através de terceiros; } \\
\text { Venda destes residuos para } \\
\text { terceiros. }\end{array}$ \\
\hline c & $\begin{array}{l}\text { Madeira } \\
\text { Papel }\end{array}$ & Aterro Industrial & $\begin{array}{l}\text { Reaproveitamento no } \\
\text { processo produtivo; } \\
\text { Eliminaçio destes residaos na } \\
\text { própria empresa; } \\
\text { Eliminaçlo destes residuos } \\
\text { através de terceiros; }\end{array}$ \\
\hline F & $\begin{array}{l}\text { Madeira } \\
\text { Plistico }\end{array}$ & Container & $\begin{array}{l}\text { Eliminaçio destes residaos na } \\
\text { própria empresa; } \\
\text { Eliminaçio destes residonos } \\
\text { através de terceiros; }\end{array}$ \\
\hline E & Papel & Caçambas & $\begin{array}{l}\text { Eliminaçio destes residuos } \\
\text { através de terceiros; } \\
\text { Venda destes residuos para } \\
\text { terceiros. }\end{array}$ \\
\hline D & Papel & Nho respondeu & $\begin{array}{l}\text { Elimimaçho destes residaos } \\
\text { através de terociros; }\end{array}$ \\
\hline \multicolumn{4}{|c|}{ Empresas que operam no exterior } \\
\hline AHLSTROM & Papel & Caçambas & Incincraçio \\
\hline FRASER PAPER & Cinzas & Näo respondeu & $\begin{array}{l}\text { Melhoramento da } \\
\text { Agricultura; } \\
\text { Alerros; }\end{array}$ \\
\hline TOL.KO & $\begin{array}{l}\text { Madeira } \\
\text { Papel }\end{array}$ & Aterro Isdustrial & Aterro Industrial \\
\hline STORA ENSO & Nāo respondku & Não Respondeu & Nio Respondeu \\
\hline WESTERN PULP & $\begin{array}{c}\text { Madeira } \\
\text { Materiais Inorgânicos }\end{array}$ & Aterro Industrial & Aterro Industrial \\
\hline $\begin{array}{c}\text { UPM } \\
\text { KYMMENE }\end{array}$ & Cinzas & Aterro Industrial & Aterro Industrial \\
\hline
\end{tabular}

Fonte: Dados da Pesquisa. 


\section{Conclusões}

Embora seja pequeno o número de empresas que responderam aos questionários, todas são de grande porte, portanto, representativas em termos de impactos ambientais. As estratégias ambientais destas empresas não estão devidamente consolidadas. Nas empresas do exterior a regulamentação governamental está presente em todas elas, no Brasil apenas em alguns casos, sendo o comportamento das empresas mais pró-ativo, talvez cedendo às pressões ambientais do mercado externo. São generalizadas as medidas preventivas referentes ao tratamento de efluentes, sólidos e líquidos e redução do consumo de energia. $O$ percentual de investimentos das empresas em meio ambiente variou bastante quando expresso em relação ao seu faturamento bruto. Estudos envolvendo um número maior de empresas revestem-se de grande importância à recomendação de políticas ambientais ao setor

\section{Referências bibliográficas:}

BRACELPA - ASSOCIAÇÃO BRASILEIRA DE CELULOSE E PAPEL Disponível em: http://www.bracelpa.org.br/informes_anuais, Acesso em: 15 jun. 2004.

BEZERRA, M.R.; SOUSA, E.P. Economia do Meio Ambiente e a Indústria Brasileira: análise das inter-relações entre as políticas ambientais e a politica industrial. In: CONGRESSO DA SOCIEDADE BRASILEIRA DE ECONOMIA E SOCIOLOGIA RURAL - SOBER, XLII. Anais... 2004

CORSON, W.H. Manual global de ecologia: o que você pode fazer a respeito da crise do meio ambiente. 4.ed. São Paulo: Augustus, 2002.

\section{ROMEIRO, A.R. Desenvolvimento Sustentável e mudança} institucional: notas preliminares, Campinas, IE - UNICAMP, 1999 (Texto para Discussão)

DONAIRE, D. Gestão ambiental na empresa. 2.ed. São Paulo: Atlas, 1999.

REIS, M.J.L. ISO 14000: gerenciamento ambiental, um novo desafio para a sua competitividade. Rio de Janeiro: Qualitymark, 1995.

BARBIERI, J.C. Gestão Ambiental Empresarial: conceitos, modelos e instrumentos. São Paulo: Saraira, 2004.
MOTTA, R.S. Analyzing the environmental performance of the brazilian industrial sector. - IPEA, Rio de Janeiro, 2004. (Texto para Discussão n.1053).

\section{Resumo:}

O processo de crescimento econômico e desenvolvimento de um país está diretamente ligado, dentre outros fatores, as atividades industriais. No entanto, a maioria das industrias possuem um processo que apresenta grande potencial de danos ao meio ambiente, que se não forem tomadas medidas para preservação, os problemas ambientais poderão se agravar. Neste sentido, o presente estudo teve por objetivo a prospecção de estratégias ambientais de empresas do setor de papel e celulose do Brasil e do Exterior, considerando que esta atividade é altamente poluente. Para tanto, foi elaborado e enviado por email às empresas que operam no Brasil e que operam no exterior um questionário composto por 45 questões abertas, fechadas e mistas, preenchido pelos entrevistados englobando seções como: informações gerais do entrevistado; caracterização da empresa; certificação ISO 9000 e 14000; produção e meio ambiente; implantação de medidas de proteção ambiental; gestão da qualidade da água; gestão de resíduos sólidos; gestão de resíduos gasosos. A análise das respostas evidencia uma maior regulação ambiental exercida sobre as empresas do exterior, quando comparadas as do Brasil. Mostra a grande preocupação de todas elas com a emissão de efluentes líquidos e consumo de energia, porém considerando na sua maioria grande disponibilidade de água para execução dos processos.

\section{Palavras-chave:}

Poluição; Gestão Ambiental; Sistema de Gestão Ambiental; Certificação ISO; Indústria de Papel e Celulose. 